\title{
Phytoprotection
}

\section{The European corn borer, Ostrinia nubilalis [Lepidoptera : Pyralidae] : a potential pest of potatoes growth on Prince Edward Island}

\section{J.G. Stewart}

Volume 73, numéro 1, 1992

URI : https://id.erudit.org/iderudit/706017ar

DOI : https://doi.org/10.7202/706017ar

Aller au sommaire du numéro

Éditeur(s)

Société de protection des plantes du Québec (SPPQ)l

ISSN

0031-9511 (imprimé)

1710-1603 (numérique)

Découvrir la revue

Citer cet article

Stewart, J. (1992). The European corn borer, Ostrinia nubilalis [Lepidoptera : Pyralidae] : a potential pest of potatoes growth on Prince Edward Island.

Phytoprotection, 73(1), 25-29. https://doi.org/10.7202/706017ar
Résumé de l'article

L'influence de la pyrale du maïs, Ostrinia nubilalis (Lepidoptera: Pyralidae) sur le rendement des pommes déterre (Solanum tuberosum 'Russet Burbank') a été évaluée à deux localités de l'île du Prince Edouard en 1989 et 1990. À Summerside, le nombre moyen de larves par tige n'a pas excédé 0,19 pour ces deux années, et aucune différence significative de rendement n'a été trouvée entre les parcelles-témoins non traitées et les parcelles protégées avec le Bacillus thuringiensisvar. kurstaki (B.t.k.). À Tryon en 1989, une moyenne saisonnière de 1,16 larves par tige a réduit les rendements totaux et vendables de 7,5 et 8,8\% respectivement, par rapport aux parcelles protégées par le B.t.k. Une tendance similaire quoique non significative a été observée en 1990 à ce même endroit. Le niveau plus élevé de dommages causés par la pyrale du maïs aux pommes de terre cultivées à l'île du Prince Edouard, par rapport aux cultures de régions plus au sud, peut être dû au plus long intervalle d'attaque. À l'île du Prince Edouard, le seuil d'action pour la pyrale du maïs sur les pommes déterre semble se situer entre 0,11 et 0,30 masse d'oeufs par tige. 


\title{
The European corn borer, Ostrinia nubilalis [Lepidopte- ra: Pyralidae]: a potential pest of potatoes grown on Prince Edward Island
}

\author{
Jeff G. Stewart ${ }^{1}$
}

Received 1991-05-06; accepted 1992-01-28

\begin{abstract}
The effects of the European corn borer, Ostrinia nubilalis [Lepidoptera: Pyralidae], on yield of 'Russet Burbank' potatoes (Solanum tuberos) um was investigated at two sites in Prince Edward Island in 1989 and 1990. At Summerside, the mean number of larvae per stalk did not exceed 0.19 in either year, and no significant differences in yield were found between untreated plots (check) and plots protected with Bacillus thuringiensis var. kurstaki(B.t.k.). At Tryon in 1989, a seasonal average of 1.16 larvae per stalk reduced total and marketable yields by $7.5 \%$ and $8.8 \%$, respectively, compared to plots protected with B.t.k. A similar but not statistically significant trend was observed in 1990 at this site. The higher degree of damage by the European corn borer to potatoes grown on P.E.I., relative to crops grown in more southernly locations, may be due to the longer interval of attack. On P.E.I., the action threshold for the European corn borer on potatoes appears to be between 0.11 and 0.30 egg masses per stalk.
\end{abstract}

Stewart, J.G. 1992. The European corn borer, Ostrinia nubilalis [Lepidoptera: Pyralidae]: a potential pest of potatoes grown on Prince Edward Island. PHYTOPROTECTION: 73: 25-29.

L'influence de la pyrale du maïs, Ostrinia nubilalis (Lepidoptera: Pyralidae) sur le rendement des pommes de terre (Solanum tuberosum 'Russet Burbank') a été évaluée à deux localités de l'île du Prince Édouard en 1989 et 1990. À Summerside, le nombre moyen de larves par tige n'a pas excédé 0,19 pour ces deux années, et aucune différence significative de rendement n'a été trouvée entre les parcelles-témoins non traitées et les parcelles protégées avec le Bacillus thuringiensis var. kurstaki (B.t.k.). À Tryon en 1989, une moyenne saisonnière de 1,16 larves par tige a réduit les rendements totaux et vendables de 7,5 et $8,8 \%$ respectivement, par rapport aux parcelles protégées par le B.t.k. Une tendance similaire quoique non significative a été observée en 1990 à ce même endroit. Le niveau plus élevé de dommages causés par la pyrale du maïs aux pommes de terre cultivées à l'île du Prince Édouard, par rapport aux cultures de régions plus au sud, peut être dû au plus long intervalle d'attaque. À I'île du Prince Édouard, le seuil d'action pour la pyrale du maïs sur les pommes de terre semble se situer entre 0,11 et 0,30 masse d'oeufs par tige.

\section{INTRODUCTION}

The European corn borer, Ostrinia nubilalis (Hübner) [Lepidoptera: Pyralidae],

1. Agriculture Canada, Research Station, P.O. Box 1210, Charlottetown, Prince Edward Island, Canada C1A 7M8. Contribution No. 760 feeds on over 200 species of plants including corn (Zea mays L.) and potatoes (Solanum tuberosum L.) (Hodgson 1928). 
Although the European corn borer attacks corn on Prince Edward Island (P.E.I.) (Thompson and White 1977), damage on potatoes by this pest was not noted until 1987. Larvae damage potatoes by entering the stem and destroying the pith, xylem, and phloem (Kennedy and Anderson 1981). Because young larvae are present on the foliage for only a few days, the 'window' for control with insecticides is quite narrow. Insecticides are ineffective after the larva enters the stem (Dill and Jones 1984). Damaged plants are susceptible to wind damage, water stress, and invasions by pathogens such as blackleg [Erwinia atroseptica (van Hall) Jennison] (Kennedy 1983).

The impact of the European corn borer on potatoes has been studied in North America by Bray (1961), Kennedy (1983), and Kennedy and Anderson (1981). Even though season-long sprays of DDT and thiodan reduced the damage by the European corn borer on 'Katahdin' potatotes, yields from the treated plots were not significantly different from the untreated check plots (Bray 1961). Kennedy (1983) found no correlation between yield of U.S. number 1 'Pungo' and the number of tunnels per plant, percent of stems with tunnels, number of stems with tunnels, or the number of dead plants per plot. Kennedy and Anderson (1981) also failed to demonstrate a strong correlation between damage of 38 holes per plant to yield of U.S. number 1 potatoes ('Pungo').

The impact of the European corn borer on potatoes has not been documented for P.E.I. and must be known before an action threshold can be established. This study was established to quantify the effects of this pest on the late season cultivar Russet Burbank.

\section{MATERIALS AND METHODS}

Two experimental sites were established near Summerside and Tryon, P.E.I. in commercial fields of 'Russet Burbank' potatoes in 1989 and 1990. The area of each site measured $28 \mathrm{~m}$ wide (about 30 rows) by $70 \mathrm{~m}$ long. Seed pieces were planted on 17 May and 5 May at Summerside in 1989 and 1990, respectively, and on 3 June and 7 June at Tryon in 1989 and 1990, respectively. The later planting of potatoes at Tryon in 1990 was due to unusually wet weather from 13 May to 30 May. Plants were spaced at approximately $0.4 \mathrm{~m}$ within rows and $0.9 \mathrm{~m}$ between rows. A granular insecticide, phorate (Thimet 15G) was applied at $3.7 \mathrm{~kg}$ a.i. $\mathrm{ha}^{-1}$ at planting at the Tryon site in 1989 and 1990, otherwise applications of insecticides were applied by the researchers from the Charlottetown research station. Cultivation, the application of herbicides, fungicides, and foliar desiccants were applied by the growers according to guidelines established for the Maritime provinces (Anonymous 1989; Asiedu etal. 1987).

The experiment was a randomized complete block design with two treatments each replicated four times at each site. The treatments were an untreated check and applications of Bacillus thuringiensis var. kurstaki (B.t.k.) (Javelin) at 63.4 Billion International Units (BIU) ha ${ }^{-1}$ after egg masses of the European corn borer were detected. The bacterial insecticide was applied on 15, 19, 29 July and 7, 23 August in 1989 and on 13, 20, 27 July and 3, 17, 23 August in 1990. Each plot measured $13 \mathrm{~m}$ wide ( 14 rows) by $12 \mathrm{~m}$ long. Blocks were separated by $3-\mathrm{m}$ roadways. Adult males of the European corn borer were monitored using the Z-strain pheromone (Great Lakes IPM, Vestaburg, Michigan) beginning in June of each year.

Heliothis-style traps (Great Lakes IPM, Vestaburg, Michigan) measuring $75 \mathrm{~cm}$ in diam at the base and $3 \mathrm{~cm}$ at the top, with a $20-\mathrm{cm}$ diam by $40-\mathrm{cm}$ tall removable cage constructed of 0.3 mesh wire were erected in a grassy area at the edge of each potato field. The pheromone was suspended at the base of the trap, about 1 $m$ above the ground. Traps were sampled each week from June until August and the number of males per trap was recorded. The pheromone was changed every other week.

Each 14-row plot was subdivided into six rows for samples and two rows for yield measurements. The first and last two rows of each plot, and two rows between the sample rows and the yield rows, were designated as buffer rows. In addition, the first and last two plants of each row were not sampled in order to 
avoid edge effects. This procedure was followed because excessive sampling for the European corn borer reduced the total and marketable yield of 'Russet Burbank' potatoes by $8 \%$ and $13 \%$, respectively (Stewart and Thompson 1988) .

Plots were sampled each week from 6 July to 9 September in 1989 and from 5 July to 13 September in 1990 for egg masses, larvae, or damage to stalks. Ten plants were randomly selected per plot. Two haulms (stalks) per plant (20 per plot) were cut at ground level and examined for the presence of various stages of the European corn borer. The Summerside site was treated each year with Bacillus thuringiensis var. tenebrionis (Trident) at a rate of 46.2 Billion Tenebrionis Units (BTU) ha $^{-1}$ on 15, 30 July and 7 August in 1989 and on 13, 19 July and 23, 30 August in 1990 for control of Colorado potato beetle [Leptinotarsa decemlineata (Say)] larvae. All insecticides were applied in a spray volume of $300 \mathrm{~L} \mathrm{ha}^{-1}$ at $240 \mathrm{kPa}$ using a $\mathrm{CO}_{2}$-pressurized precision plot sprayer equipped with two overhead disc-core hollow nozzles per row.

The growers applied the desiccant diquat $\left(6,7\right.$-dihydrodipyrido $\left[1,2-\alpha: 2^{\prime}, 1^{\prime}-c\right]$ pyrazinediium ion) at $550 \mathrm{~g}$ a.i. ha- ${ }^{-1}$ either in late September or early October of each year. About $7.6 \mathrm{~m}$ of row were harvested by hand from the two rows reserved for yield evaluation in each plot. Tubers were counted, weighed, and graded as total yield and marketable (tubers $>40 \mathrm{~mm}$ ) yield. Tubers were harvested from eight 7.6-m sections of row from the portion of the field managed by the grower so that the yields of the experimental plots and commercially-managed fields could be compared.
The data were analyzed using MEANS and ANOVA procedures of SAS (SAS Institute Inc. 1988). Least Significant Difference (LSD) were calculated for means if the treatment effects were significant at $P \leq 0.05$.

\section{RESULTS AND DISCUSSION}

The number of European corn borer per stalk never exceeded 0.19 for either the check or the B.t.k. plots in either 1989 or 1990 at the Summerside location. The marketable or total yield of tubers $(\mathrm{kg}$ per $7.6 \mathrm{~m}$ row) from the check and B.t.k. plots was not significantly different and averaged 13.0 for marketable tubers and 18.7 for total tubers in 1989, and 18.8 for marketable tubers and 24.4 for total tubers in 1990.

European corn borer males were first detected at Tryon in 1989 on 6 June [284 degree days (DD), base $10^{\circ} \mathrm{C}$ ] and reached seven per trap on both 13 July (336 DD) and on 20 July (380 DD). In 1990, males were first found on 6 July (229 DD) and reached a peak of eight per trap on 12 July (270 DD).

The average number of egg masses per stalk was similar for either treatment in 1989 and 1990 (Table 1). Peak numbers of egg masses per stalk were observed on 14 July 1989 (0.30) and on 27 July $1990(0.11)$. Larvae were first detected at the Tryon site 1 wk earlier in 1989 (27 July) compared with 1990. The mean number of larvae or holes per stalk per week of the check plots was significantly greater than that of the plots protected with B.t.k. (Table 1). This suggests that treating the crop with a bacterial insecticide reduced the

Table 1. Seasonal averages for various growth stages of the European corn borer and damage to 'Russet Burbank' potatoes, Tryon, P.E.I., 1989 and 1990

\begin{tabular}{|c|c|c|c|c|}
\hline \multirow[b]{2}{*}{ Year } & \multirow[b]{2}{*}{ Treatment } & \multicolumn{3}{|c|}{ Mean number stalk-1 $w^{-1}$} \\
\hline & & Egg masses & Larvae & Holes \\
\hline \multirow[t]{2}{*}{1989} & Check & 0.07 & 1.16 & 1.65 \\
\hline & B.t.k. ${ }^{a}$ & 0.07 & 0.20 & 0.41 \\
\hline \multirow[t]{3}{*}{1990} & Check & 0.04 & 1.23 & 1.67 \\
\hline & B.t.k. & 0.04 & 0.10 & 0.17 \\
\hline & $\operatorname{LSD}(P=0.05)$ & 0.04 & 0.36 & 0.51 \\
\hline
\end{tabular}

${ }^{a}$ B.t.k.:Bacillus thuringiensis var. kurstaki was applied at $63.4 \mathrm{BIU} \mathrm{ha}^{-1}$. 
Table 2. Yield of 'Russet Burbank' potatoes damaged by the European corn borer, Tryon, P.E.I., 1989 and 1990

\begin{tabular}{|c|c|c|c|c|c|c|c|}
\hline \multirow[b]{2}{*}{ Year } & \multirow[b]{2}{*}{ Treatment } & \multicolumn{2}{|c|}{$\begin{array}{c}\text { Mean tuber weight } \\
\left(\mathrm{t} \mathrm{ha}^{-1}\right)\end{array}$} & \multicolumn{2}{|c|}{$\begin{array}{c}\text { Mean number of } \\
\text { tubers ha }\end{array}$} & \multicolumn{2}{|c|}{$\begin{array}{c}\text { Tuber density } \\
\left(\mathrm{g} \text { tuber }^{-1}\right)\end{array}$} \\
\hline & & Total & Marketable & Total & Marketable & Total & Marketable \\
\hline \multirow[t]{4}{*}{1989} & Check & 37.0 & 32.6 & 315741 & 200651 & 118 & 158 \\
\hline & B.t.k. $^{a}$ & 40.0 & 35.7 & 312871 & 225016 & 132 & 163 \\
\hline & Grower & 37.0 & 32.7 & 334758 & 225016 & 117 & 150 \\
\hline & $\operatorname{LSD}(P=0.05)$ & 2.0 & 2.3 & 58616 & 28966 & 17 & 17 \\
\hline \multirow[t]{4}{*}{1990} & Check & 38.0 & 26.6 & 370458 & 159984 & 103 & 167 \\
\hline & B.t.k. & 40.7 & 30.6 & 343548 & 168225 & 120 & 182 \\
\hline & Grower & 41.0 & 31.0 & 356644 & 186677 & 115 & 167 \\
\hline & $\operatorname{LSD}(P=0.05)$ & 4.5 & 4.3 & 36185 & 27124 & 11 & 15 \\
\hline
\end{tabular}

${ }^{a}$ B.t.k.: Bacillus thuringiensis var. kurstaki was applied at $63.4 \mathrm{BIU} \mathrm{ha}^{-1}$.

number of corn borer larvae per stalk. Since only newly-hatched larvae feed on foliage, it was assumed that mortality occurred during the first stadium.

Protecting plots with B.t.k. resulted in higher total and marketable yields of tuber compared with the untreated check in 1989 at the Tryon site (Table 2). Although not significant, this trend was also apparent for 1990. The yield of tubers from the grower's plot was similar to the check in 1989 and the B.t.k. plots in 1990 because the grower did not use an insecticide to control the corn borer in 1989 but did in 1990. The reduction in yield is attributed to the European corn borer as the population of other potato pests per stalk never exceeded 1.0 for the Colorado potato beetle, 0.1 for the potato flea beetle [Epitrix cucumeris (Harris)], and 1.7 for aphids in either 1989 or 1990 . In the absence of phorate, damage by larvae of the European corn borer could have been more pronounced. Szeto et al. (1990) found residues of $2.4 \mu \mathrm{L} \mathrm{L}^{-1}$ phorate in leaf tissue of potatoes $65 \mathrm{~d}$ after emergence in a silt loam soil in British Columbia. The soil at the Tryon site is a sandy loam ( $B$. Thompson 1991, personal communication). The efficacy of phorate, if any, under P.E.I. conditions $60 \mathrm{~d}$ after planting, when egg masses begin to hatch, remains to be determined. However, even though phorate was used at planting, larvae were present in sufficient numbers to reduce tuber yields in 1989 (Table 2).

The mean number of tubers harvested from the check, B.t.k., or grower's plots were not statistically different (Table 2). Mean tuber density of plots treated with B.t.k. tended to be greater than the untreated plots in 1989. This trend was significant for total tubers in 1990.

Damage by the European corn borer at Tryon, in spite of the application of a granular insecticide at planting, suggests that much of the efficacy of this insecticide is lost by the time larvae attack potatoes, making this insect a potential pest of lateseason potatoes grown on P.E.I. Greater damage by the European corn borer to potatoes grown on P.E.I. may be due to the longer interval of attack relative to crops grown in Delaware (Bray 1961) or in North Carolina (Kennedy 1983). Kennedy (1983) indicated that other environmental factors had more impact on yield than the European corn borer alone. However, the difference in abundance of this pest at the Tryon and Summerside sites could not be explained. Further research on the biology of the European corn borer on potatoes, including its overwintering sites, is needed.

The lack of a significant reduction in marketable or total yields at Tryon in 1990 is consistent with other studies (Bray 1961; Kennedy 1983; Kennedy and Anderson 1981) where researchers have had difficulty relating damage by the European corn borer to yield losses of potatoes. Results of this study suggest that the action threshold may be between a seasonal peak of 0.11 and 0.30 egg masses per stalk. Future studies are required to refine the threshold and to determine how environmental conditions interact 
with damage induced by the European corn borer.

\section{ACKNOWLEDGEMENTS}

The author thanks Mr. David Best and Linkletter Farms Inc. for access to their fields. Thanks are also extended to Sandoz Corp. for supplying the bacterial insecticides. The technical assistance of Jim Lund, Mary Smith, Andrew Dornan, and the summer students is gratefully acknowledged.

\section{REFERENCES}

Anonymous. 1989. Potato crop variety, weed and pest control recommendations for the Atlantic Provinces. Advisory Committee on Potatoes. Agdex 257, Publ. No. 1300A, 15 pp.

Asiedu, S., S.E. Coleman, T. Haliburton, and M.C. Hampson (Eds.). 1987. Atlantic Canada Potato Guide. Advisory Committee on Potatoes. Agdex 257/13, Publ. No. 1300, 47 pp.

Bray, D.F. 1961. European corn borer in potatoes. J. Econ. Entomol. 54: 782-784.

Dill, J.F., and R.T. Jones. 1984. European corn borer. IPM Fact Sheet 107, Cooperative Extension Service, University of Maine at Orono, $2 \mathrm{pp}$.

Hodgson, B.E. 1928. The host plants of the European corn borer. Pages 1-63 in New England. Bull. No. 77, U.S.D.A.

Kennedy, G.G. 1983. Effects of European corn borer (Lepidoptera: Pyralidae) damage on yields of spring-grown potatoes. J. Econ. Entomol. 76: 316-322.

Kennedy, G.G., and T.E. Anderson. 1981. Considerations for management of the European corn borer on potatoes. Pages 204-222 in J.H. Lashomb and R.A. Casagrande (eds.), Advances in potato pest management. Hutchinson Ross Publ., Stroudsburg, $\mathrm{Pa}$.

S.A.S. Institute Inc. 1988. SAS procedures guide for personal computers, Version 6.03 Edition. Cary, N.C., 441 pp.

Stewart, J.G., and L.S. Thompson. 1988. Impact of the European corn borer on yield of potatoes. Research Summary, Research Station, Charlottetown, P.E.I. p. 63.

Szeto, S.Y., P.M. Price, J.R. MacKenzie, and R.S. Vernon. 1990. Persistence and uptake of phorate in mineral and organic soils. J. Agric. Food Chem. 38: 501-504.

Thompson, L.S., and R.P. White. 1977. Effects of insecticides on European corn borer and yield of silage corn in Prince Edward Island. J. Econ. Entomol. 70: 706-708. 